6) Effects of hydrocortisone orally administered on diurnal rhythms in the excretion of total 17-OHaS and 17-KS pattern in urine were observed in 2 healthy adults. The decrease in Fraciion III was more sensitive compared with the changes of other fractions, and Fraction VI and VII were shown rather increased slightly following hydrocortisone administration.

It is suggested that the dynamic observation on urinary 17 -ketosteroids pattern comparing with urinary total 17-hydroxycorticosteroids is contributed to elucidate the metabolism of adrenocortical steroid hormones. The clinical significances of certain fractions in urinary 17-ketosteroids with regard to biosynthesis and metabolism of adrocortical hormones were discussed.

\title{
Studies on the Possible Relation between Adrenocortical Function and Progress \& Prognosis of TB Cases
}

\author{
By
}

\section{Seiichi SATO}

First Department of Internal Medicine, Nagoya University of Medicine (Prof. S. Hibino) Aichi National Sanatorium (Ghief K. Kuno)

In connection with some TB cases who were attacked by the disease and have been medically treated all under the simillar environments and conditions, I conducted a series of research into any possible connection to be traced between their different development and adrenocortical function thereby hoping to check any possibility of obtaining a clue to the problem of human constitution serving as one factor in question. My observations of the adrenocortical function, which were carried out with the minimal pulmonary TB cases with the same status at the time of this study, were effected for the two opposing groups of the cases respectively from the following view points :

1) Any aggravation in the course of chemotherapy after their reaching $T P$ in the past.

2) Degree of improvement of their X-ray observations after the same chemotherapy.

3) Degree of their complaints.

The above comparative study of the function brought about the following results :

The group of cases who suffered a relapse of TB in the course chemotherapy in the past, the group of those who showed no or slight in provement of X-ray observations after chemotherapy and also the group with a greater number of complainte showed a greater decline of adrenocortical function than recorded by their respective opposings : groups of cases who had not a relapse of TB in the past, of those who showed a remarkable improvement of X-ray observations, and of those with a smaller number of complaints. From these results it is to be inferred that the degree of the adrenocortical function has some bearing upon the development, especially a relapse or aggravation of TB cases. 


\title{
副㛑皮質機能と肺結核症の経過予後との
}

\author{
関連に関する研究 \\ 名古屋大学医学部第一講座 (主任 日比野進教授) \\ 国立愛知 療養 所 (所長 久野㗨博士) \\ 佐藤 制 一 \\ 腥言
}

近年ストレプトマイシン，パス，ヒ、トラヂット等強力な抗結核夙が発見されるに及んで結核症の経過は著 しく短縮され予後を良好ならしめたが，一方同一状態で発病し同一条件の下に化学療法を受けていながら縚 過にわいて差の見られる專は臨床上少なからず経験する所である。元来結核症は体質学的観察がなされてわ り結核症構成の因子として体質の重要性む認められている, Selye)の Stress と General Adaptation Syndrom の概念の提唱以来，脳下垂体副腎皮質系の機能が生体に対し大きな意義を持つてとが明かになつた，以来結 核症と副腎皮䨘系機能の関係も幾多の研究者 ${ }^{12)-18)}$ により種々報告されており肺結核症において副腎皮質機 能に異常のあるととが知られている。私は同一環境同一条件下で発病し加療していながら違つた経過を辿る 症例の存在と副腎皮質系機能との間の関連に就いて検討を試み, 所謂体質の問題の解明の一つの手がかりと なるや否やを考察した。即ち私は現在同样な現症を有する軽症肺結核患者群について 1 ，既往における化学 療法中の再発の有無. 2. 同様化学療法による胸部レ線所見改善度の良否. 3. 愁訴の多宾. 以上により夫 タ二つの群に大別して，その副㹂皮質系機能を比較検討し興味ある所見を得た。

\section{第 1 篇 肺結核症の既往再無と副瞥皮質機能}

\section{第 1 章 検 查 対 象}

現在 NTA 分類で軽度進展, 学研分類で $B_{1}$ に属し且つ Target Point（以众TP と略す）に到達しており 化学璄法施行中の年令 20 才より 40 才迄の肺結核患者群を既往再発群（以众再発群と略す）之既往無再発群 （以後無再発群と略す）に分けた．再発群とは曾つて TP 到達後に化学療法中に胸部レ線所見上悪化が見られ

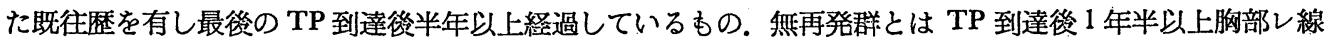
所見上悪化が見られなかつたものである.

\section{第 2 章 研 究 方 法}

\section{第 1 遾 尿中 17=Ketosteroid 1 日排泄値}

17-Ketosteroid（以後17KSと略す）の測定は Zimmerman-三宅の変法 ${ }^{19}$ 亿従い Leitz 光電比色計により行つ $た^{200)}$. 私は17KS 1 日排泄值の正常排泄域を三宅の基準21亿従い，その性年令における棄却限界值を以てし， この正常排泄域に達せぬ症例を異常低值とし正常排泄域を越へる症例を異常高值とした．尚三宅による正常

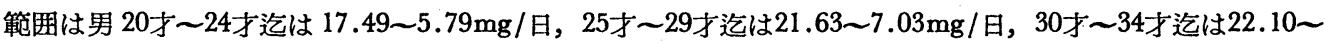
$7.38 \mathrm{mg} /$ 日，35才〜39才迄は 20.73〜7.31 mg/日，女 20 才〜29才迄は 15.23〜4.15mg/日，30才〜39才迄は $14.05 \sim 3.91 \mathrm{mg}$ /日である。

\section{第 2 筐 尿中17=Hydroxycorticoid 1 日排泄值}

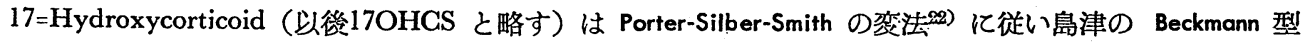
DU分光々度計で測定した．私が測定した18才より40才迄の健常人男女15例の 17 OHCS 1 日排泄值は性年令 に差がなく平均7.84mg/日でその排泄分布は13.37〜3.34mg/日であつた。尚 $17 \mathrm{KS}, 17 \mathrm{OHCS} 1$ 日排泄值は 
1 日尿を連続 3 日採取測定し，その平均值をとつた。

\section{第3 管 ACTH-gel Test}

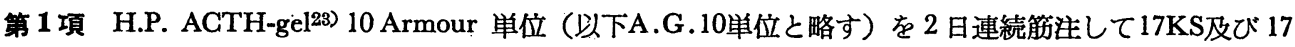
OHCS 值の時間的分布百分率測定 : 検査日の午前 8 時に A.G. 10篻位を筋注し午後 8 時迄の12時間の前半尿 と以後翌朝 8 時迄の 12 時間の後半尿中の $17 \mathrm{KS}, 17 \mathrm{OHCS}$ 值を後半尿中の值を 1 として比率に求めた。翌日 あ同䇐に行つた.

第 2 項 A.G. 10 単位 2 日連続筋注による 17KS, 17OHCS 堌加率測定. A.G. 10 単位筋注による 17KS, 17OHCS 增加率を30\%の増加を基準として，夫々增加率を梌討した。

第 3 項 A.G. 10單位 2 日連続筋注答つ流血中好酸球, 淋巴球娍少率測定：1）好酸球は Hinklemann 液染 色. 淋巴球は白血球総数を算定し同時に作つた血液垐抹標本より間接的に計算した。2) 梌查日は午前 8 時に A.G. 10単位を筋注し注射前，注射食 2 時間毎（但し好酸球は注射後 2 時間目を略す）に10時間目迄流血中好 酸球，淋巴球つ実数を求め，その減少率を測定した。翌日あ同様に行つた，3）A.G.筋注による 流血中好酸 球減少率は小西 ${ }^{24)}$ 亿従い50\%以上を正常とし，淋巴球減少率は50\%を基準にして検討した。

\section{第 4 筫 トルコ鞍について}

私は泉 ${ }^{25)}$ の方法に從い撮影し而してトルコ鞍形熊の分類も泉 ${ }^{26)}$ の方法に従いトルコ鞍の歪の高度な盃形， 扁平形，鞍橋形成，不定形を一括異常形とした他にその形が著しく小さいすのす異常形に含めた.

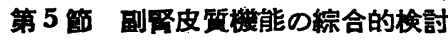

副腎皮質機能検查を一括して1）17KS 1 日排泄值が正常排泄域にあるあの，2）A. G. 筋注による 17KS， 17OHCS 增加率か30\%以上のもの. 3) A.G. 筋注に上る流血中好酸球，淋巴球减少率が50\%以上のものを其 々(+)として副緊皮質僟能を綜合的に検討した。推計学はすべて Fisher の直接確率計算法に Yates の修正 を加へて検討した。

\section{第3章 研 究 成 繶}

\section{第 1 笛 $17 \mathrm{KS}, 17 \mathrm{OHCS} 1$ 日排泄值}

第 1 項 $17 \mathrm{KS} 1$ 日排泄值は無再発群 13 例平均 $11.0 \mathrm{mg} /$ 日，再発群 13 例平均 $7.8 \mathrm{mg} /$ 日であり，異常低值例 は無再発群 13 例中 2 例 $(12.5 \%)$ ，再発群 13 例中 5 例 (38.4\%) であつた. 異常高值例は再発群に 1 例あるか ら再発群の異常排泄例は13例中 6 例 $(46.1 \%)$ となり両群間で推計学的に4.3\%の危険率で有意差を認めた。

第 2 項 $17 \mathrm{OHCS} 1$ 日排泄值は無再発群 13 例平均が $5.5 \mathrm{mg} /$ 日，再発群 13 例平均は $5.7 \mathrm{mg} /$ 日で共に健常人 平均より低值であつたが両群間で差はなかつた。

\section{第 2 節 A.G. Test}

第 1 項 A.G. 10 単位 2 日連続筋注による17KS，17OHCS 值の時間的分布百分率測定. 1) A.G. 筋注後 12 特間に排泄される $17 \mathrm{KS}$ 値の 1 日排泄值に対する百分率は第 1 日注射後無再発群 16 例平均が $55.0 \%$, 再発群 13 例平均か $56.6 \%$ であり, 第 2 日注射後は無再発群 16 例平均 $51.3 \%$, 再発群 11 例平均 $52.1 \%$ であつて両群で 余り差がなかつた，2）A.G. 筋注後12時間に排泄される 17 OHCS 值の 1 日排泄值に対する 百分率は第 1 日 注射後無再発群12例平均か $369.3 \%$, 再発群 11 例平均 $63.3 \%$ であり，第 2 日注射後無再発群 12 例平均 $64.6 \%$, 再発群 9 例平均 $62.5 \%$ であた。.今 A.G. 筋注後 12 時間目を境として前半尿と後半尿中の17OHCS 值につき， 後半尿の值を 1 として前半尿との此率を求めると, 無再発群では第 1 日, 第 2 日で其々 $2.68,2.10 て ゙ あ り$ 再 発群では1.60，1.53であつた。

第 2 項 A.G. 10笚位 2 日連続筋注による $17 \mathrm{KS}, 17 \mathrm{OHCS}$ 増加率。1) 17KS 増加率は第 1 日が無再発群 16 例平均 $27.3 \%$, 再発群 12 例平均 $27.7 \%$ であり, 第 2 日は無再発群 16 例平均 $17.0 \%$, 再発群 11 例平均 $8.8 \%$ であつた。 又増加率が30\%以上の症例は無再発群16例中 7 例 (41.2\%), 再発群12例中 4 例 $(33.3 \%)$ であ つた. 尚, A.G. 筋注前の17KS 1 日排泄值が正常排泄域以下にあつた症例で A.G. 筋注に上り $17 \mathrm{KS}$ の30\% 以上の増加を見た症例は無再発群では 2 例中 2 例，再発群では 6 例中 1 例であつた，2）17OHCS 堌加事は 


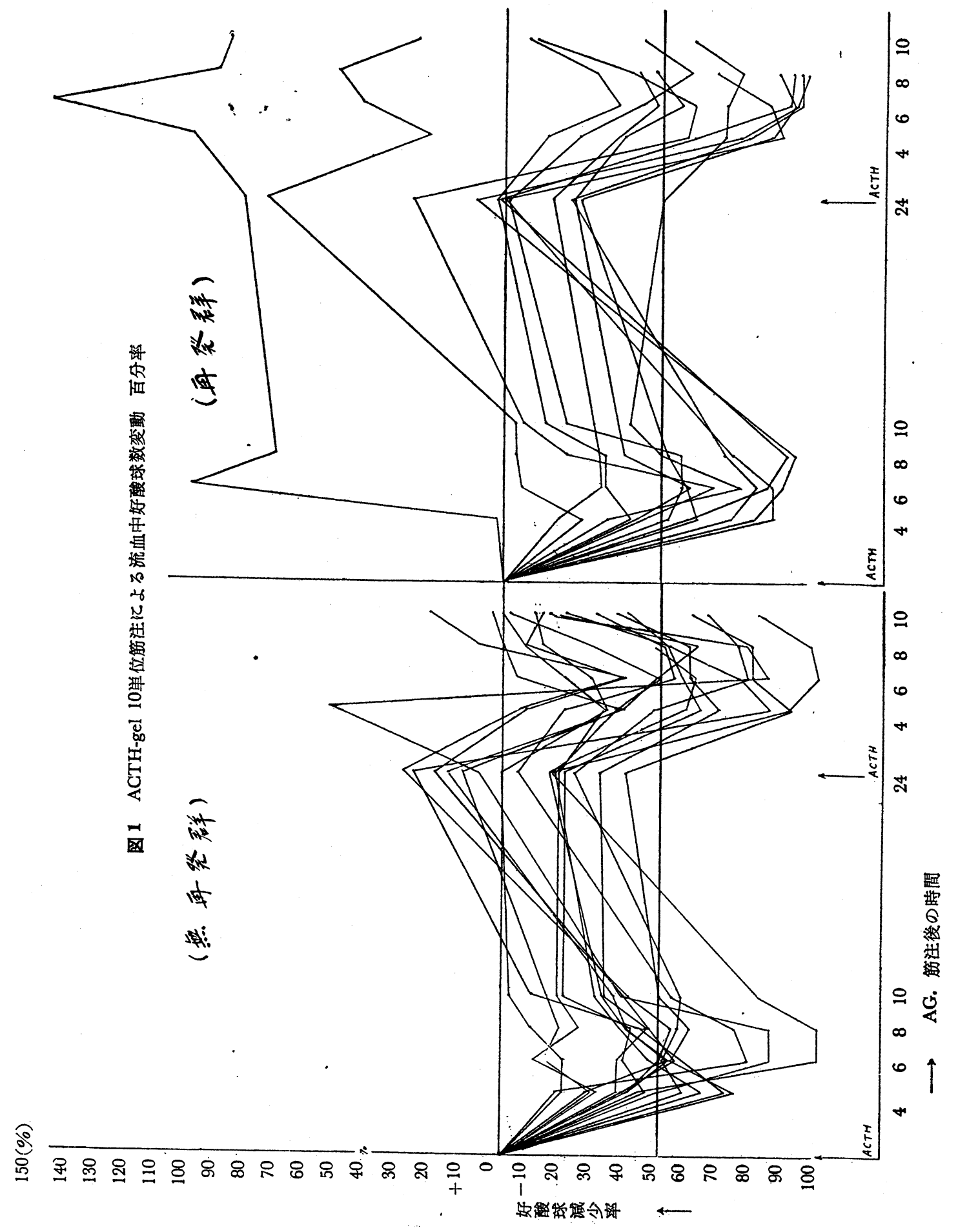




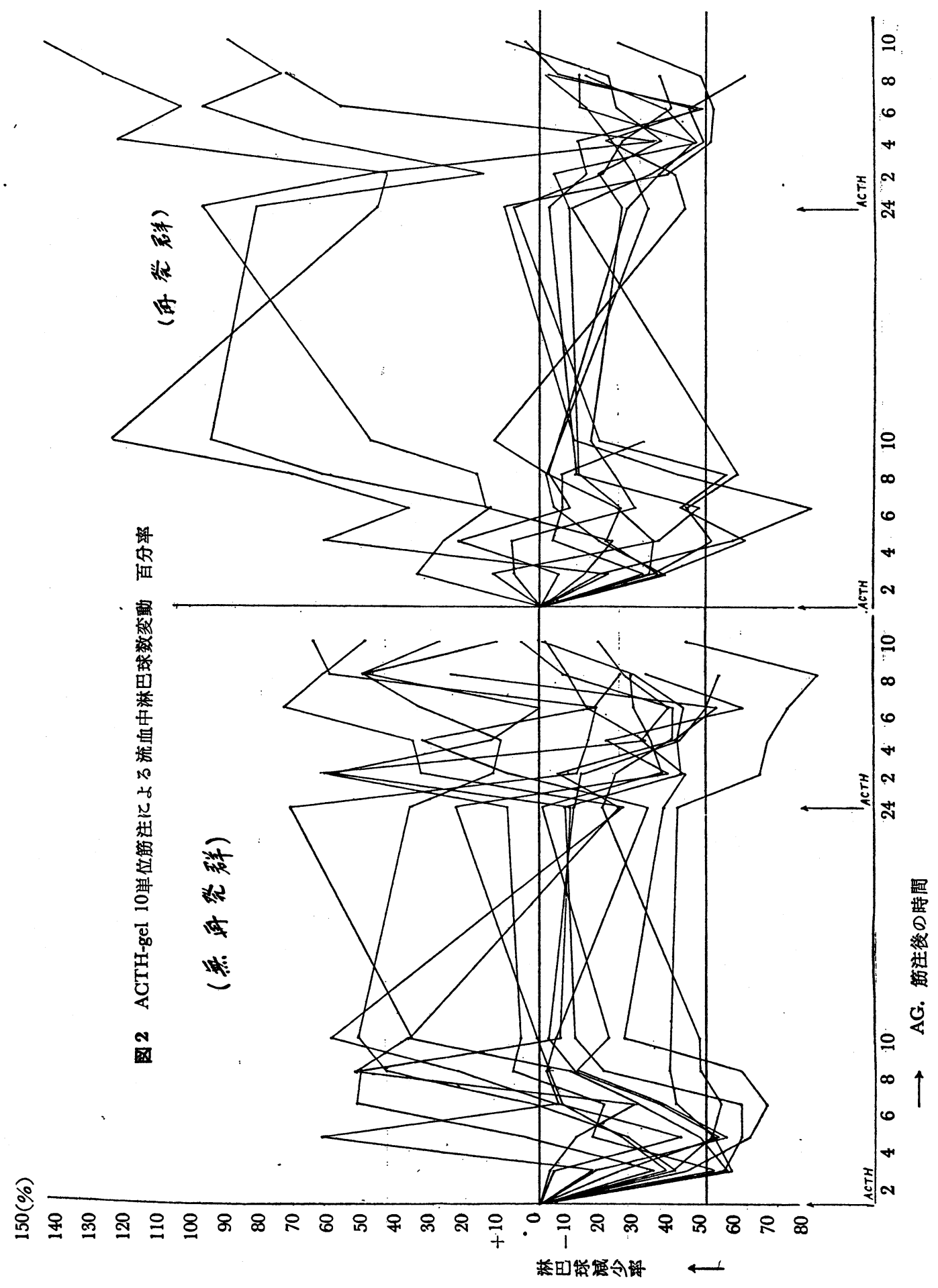


第 1 日無再発群 12 例平均か $350.3 \%$ ，再発群 11 例平均が $15.3 \%$ あり，第 2 日無再発群 12 例平均 $24.3 \%$ ，再発 群 9 例平均一 $5.0 \%$ であつた. $30 \%$ 以上の増加を示した症例は無再発群12例中 5 例 (41.6\%), 再発群11例中 2 例 $(18.1 \%)$ であつた。しかし推計学上有意差はなかつた。

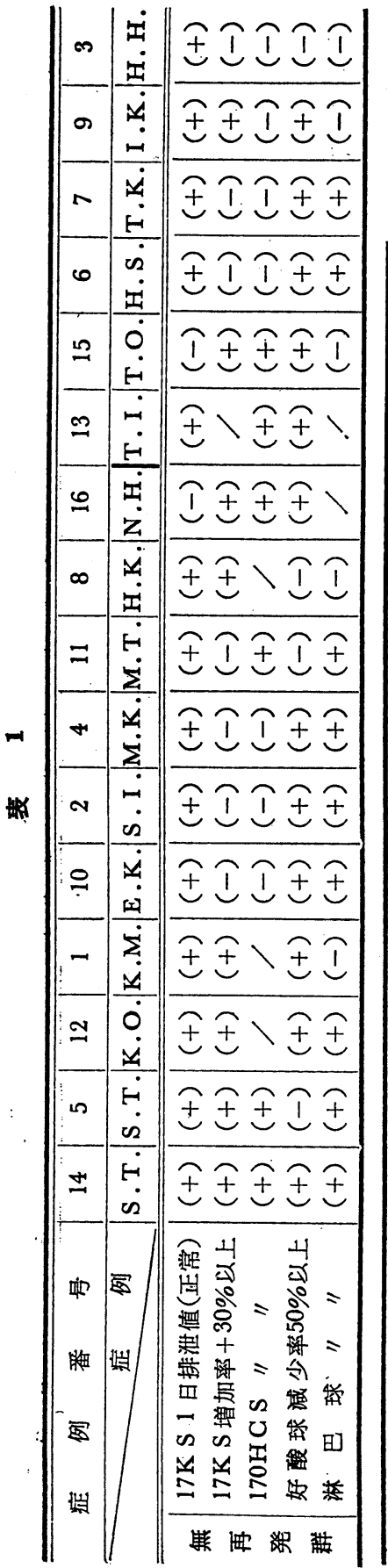

第 3 項 A.G. 10 単位 2 日連続筋注䒺の 流血中好酸球，淋巴球減 少率，1）好酸球娍少率は図 1 亿示す如く $50 \%$ 以下の減少率を示す 症例は無再発群16例中 3 例 $(19.3 \%)$, 再発群13例中 4 例 $(30.7 \%)$ であり，再発群には A.G. 笳注で逆に好酸球增加症例があつた。 2) 淋巴球減少率は図 2 の如く50\%以上の減少率に達した症例は無再発 群で14例中 9 例 $(64.2 \%)$, 再発群では 13 例中 3 例 $(23.0 \%)$ であ
ลิ

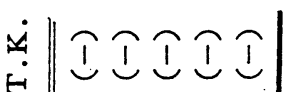

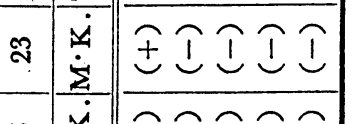

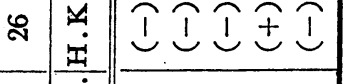

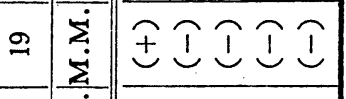
り推計学上 $3.4 \%$ の危険率で有意義 があつた. A.G.筋注により50\%以上 の減少率を示した症例の中で筋注後 4 時間以内に $50 \%$ 亿達した症例は無 再発群では 9 例中 8 例 $(88.9 \%)$, 再発群では 3 例中 2 例 $(66.7 \%)$ で あつた. 尚再発群には A.G. 筋注に より淋巴球减少を見ず逆㵔明な増 加を示した症例が 2 例あつた。

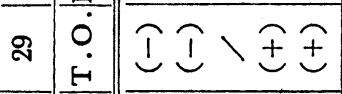

$\infty$

કさ】さI

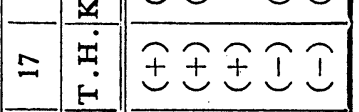

a

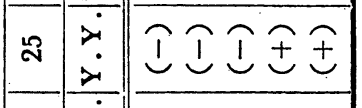

ส

ล

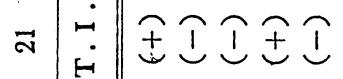

๙

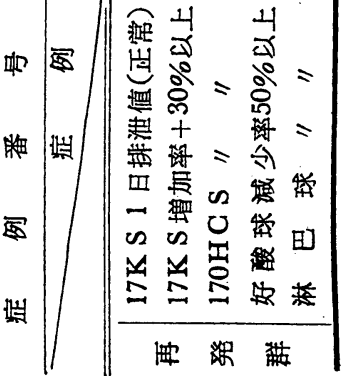

\section{第3節 両群とトルコ舵との間保}

トルコ鞍異常型を呈する症例は無 再発群 16 例中 5 例 $(31.3 \%)$, 再発 群13例中 7 例 $(53.8 \%)$ であり有意 差はなかつた。

第 4 管 両群之副筒皮質機能の総 括的倹封につ々て，即ち第 2 章第 4 節に述べた記載住従つて両群で各㱏 例につき検討してみると表 1 の如く， てれら 5 種煩の副等賀機能恰查の中 3 種類以上に $(+)$ の店例は無再発 群16例中13例(81.2\%), 再発群13例 中 4 例(30.7\%)であつて推計学的に $1.0 \%$ 以下の危険率で有意の差が見ら れた。

第4章 小，括

同様な現店を有し TP 亿到達して 居る軽店肺結㤥者群を以前に TP 到 達赑化学療法中に再発を見た再発群 と再発なしに経過した無再発群に分 けて両群つ副筒皮賀機能釦查を行い 同時にトルコ鞍との関連をあ比较検 討した，1）再発群には $17 \mathrm{KS} 1$ 日排 泄值が正常排泄域外の应例が多く推 
計学上両群間有意差があつた．2)17OHCS 1 日排泄值は大体正常範囲内にあつたが蚛群共その平均值は健 常人平均上り低值であつた. 3) 午前 8 時 A.G. 筋注後12時間以内の前半尿と以後の後半尿中17KS, 17OHCS 值について後半永の值を 1 として比率を求めると再発群の比率は $17 \mathrm{KS}$ では余り差がなかつたが 17OHCS では無再発群の比率上り小であつた.4) A.G. 筋注後 $17 \mathrm{KS}$ 増加率平均は再発群に低く各症例で増加率 $30 \%$ 以上を示したあのは再発群に少ない傾向があつた。 5) A.G. 筋注による 17OHCS 増加率平均は無再発群に 比し再発群は低く又増加率30\%以上を示した症例も再発群に少ない傾向を認めた。 6) A.G. 筋注後流血中好 酸球减少率が50\%に達しない症例は再発群に多い傾向があつた. 7) A.G. 筋注後淋巴球减少率が50\%以下の 症例は再発群に多く推計学上有意差があつた．8）再発群にトルコ鞍異常者が多い様であつた．9）総合的副 留皮實機能検査で 3 種以上に正常值或いは上く反応した症例は再発群に少なかつた。 之は両群間で推計学的 に有意であつた，以上の成績より現在同様な現症を有する軽症肺結核患者であ既往において化学療法中の再 発を経験せる症例と再発を見ずに経過せる症例の副腎皮質機能に差が認められた。

\section{第 2 篇 肺結核症の化学療法中の胸部レ線所見改善度と副腎皮蜇系機能について}

\section{第 1 章 検 查 対 象}

対象は現在胸部レ線所見が NTA 分類で軽度進展, 学研分類で $B_{1}$ の現店を有する20才より 35 才迄の肺結 核患者の中より発病時胸部レ線所見が NTA 分類で軽症或いは中等症，学研分類で $\mathrm{B}_{1}$ 或いは $\mathrm{B}_{2}$ であり同 一環境同一条件で加療し発病後現在に至る約 2 年間の化学療法施行中の胸部レ線所見が学研の病状判定基準 により著明改善をみた群と軽度改善又は不変であつた症例群に別け，一応前者を改善群，後者を不変群と名 付けて取り扱つた。

\section{第 2 章 研 究 方 法}

対象の両群につき第 1 篇, 第 2 章と同じ方法により副腎皮筫系機能検查を行い比較検討した。

\section{第3 章 研 究 成 績}

\section{第 1 管 17KS，17OHCS 1 日排泄值}

第 1 項 $17 \mathrm{KS} 1$ 日排泄值は改善群20例平均が $10.3 \mathrm{mg} /$ 日, 不変群 15 例平均が7.3mg/日であり異常低值例 は改善群 20 例中 2 例 $(10.0 \%)$, 不変群15例中 5 例 $(33.3 \%)$ であり不変群に異常高值例が 1 例あるので, 異 常排泄例として15例中 6 例 $(40.0 \%)$ となり両群間で推計学上 $4.3 \%$ の危険率で有意差があつた。

第 2 項 $17 \mathrm{OHCS} 1$ 日排泄值は両群共大体正常範囲内にあり改善群 19 例平均か $5.40 \mathrm{mg} /$ 日, 不变群 15 例平 均が5.23 $\mathrm{mg} /$ 日で健常人平均值に比し低值であるが両群で差はなかつた。

第 2 箅 A.G. Test

第 1 項 A.G. 10算位 2 日連続筋注による 17KS, 17OHCS 排泄值の時間的分布百分率. 1) 午前 8 時にA.G. 筋注後12時間以内に排泄される $17 \mathrm{KS}$ 值の 1 日排泄值に対する 百分率は第 1 日筋注後改善群 18 例の平均は $63.0 \%$ ，第 2 日は $62.1 \%$ ，不変群では第 1 日 15 例平均 $55.2 \%$ ，第 2 日 13 例平均 $51.7 \%$ ありり筋注後 12 時間目 を境にして前半尿と後半尿中 $17 \mathrm{KS}$ 值の比率を求めると改善群は其々 $1.73,1.63$ 不変群では1.23，1.07であ つた. 2) A.G. 筋注後12時間以内に排泄される 17OHCS 值の 1 日排泄值に対する百分率は改善群 15例平均 で第 1 日70.0\%，第 2 日 $69.0 \%$ 不変群は第 1 日14例平均 $66.8 \%$ ，第 2 日 12 例平均 $64.6 \%$ であり，17KS と同 样化此率を求めると改善群は其々 $2.33,2.22$ 不変群では $2.01,1.82$ であつた。

第 2 項 A.G. 10笚位 2 日連続筋注による $17 \mathrm{KS}, 17 \mathrm{OHCS}$ 增加率。1) 17KS 增加率は第 1 日筋注後改善 群 18 例平均が $14.2 \%$, 第 2 日 17 例平均 $-4.1 \%$ であり不変群では第 1 日 14 例平均 $33.2 \%$, 第 2 日 12 例平均 33.8 $\%$ だあた. $17 \mathrm{KS}$ 増加率 30\%以上の症例は改善群 18例中 6 例 (33.3\%), 不変群 14例中 6 例 (42.8\%) で あつた，2） $17 \mathrm{OHCS}$ 增加率は改善群15例平均が第 1 日 $19.0 \%$, 第 2 日 $23.2 \%$, 不変群では第 1 日 14例平均 $19.3 \%$ ，第 2 日 12 例平均 $20.1 \%$ であうた。 $17 \mathrm{OHCS}$ 堌加率 $30 \%$ 以上の症例は改善群 15 例中 4 例 (26.6\%), 不変群14例中 8 例 $(57.1 \%)$ であつた. しかし推計学上有意ではなかつた。 


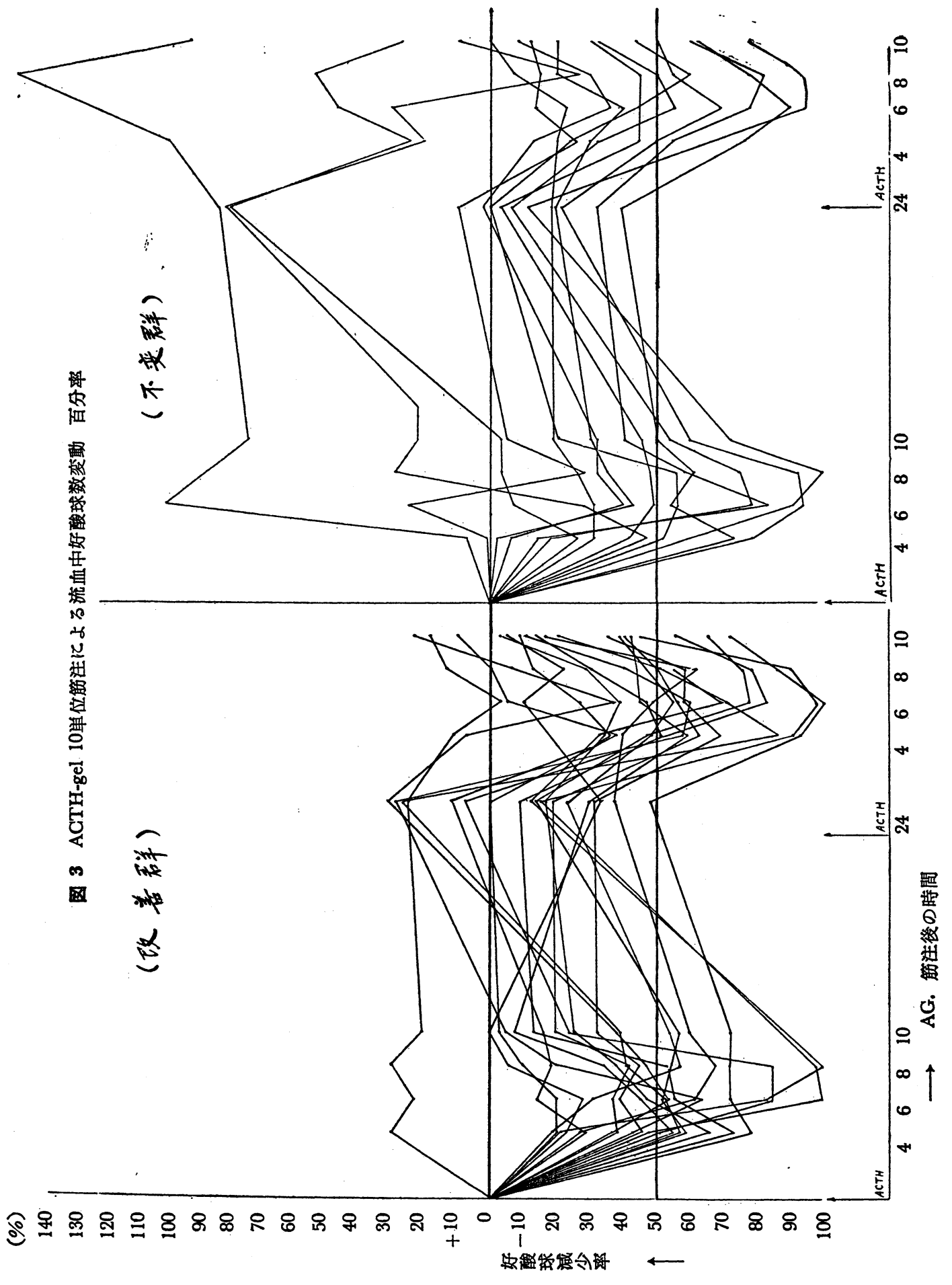


-日本内分脑学会雑誌

801

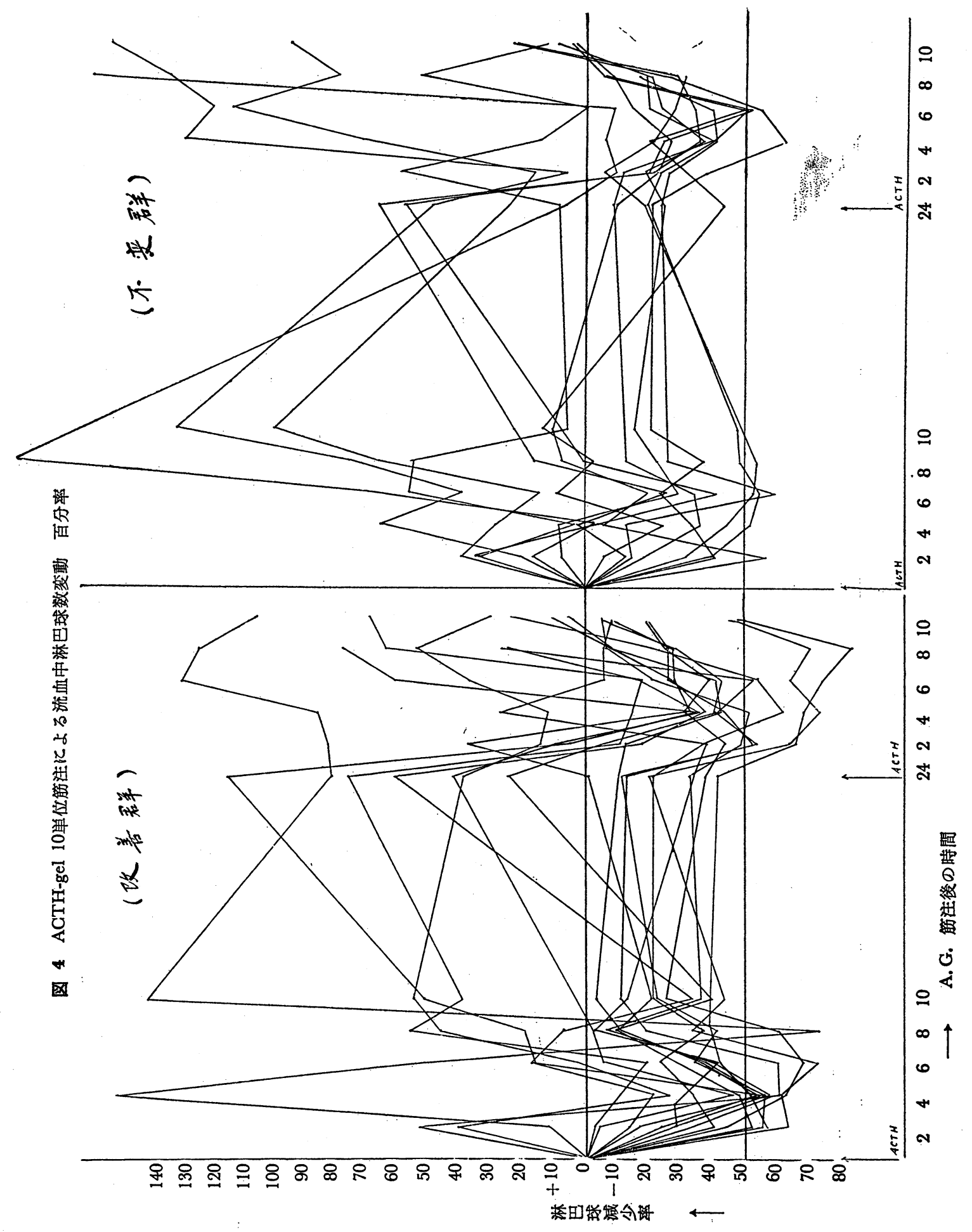




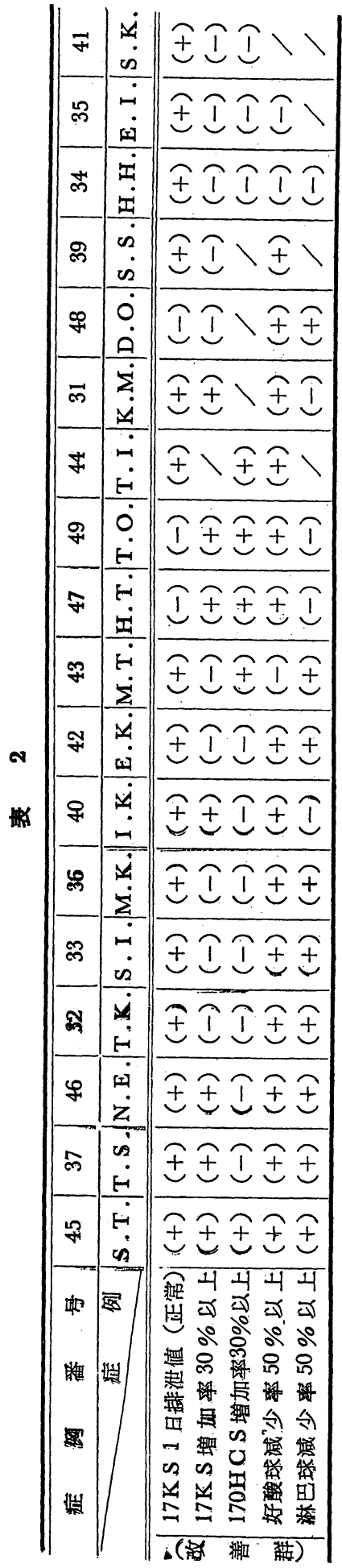

第 3 項 A.G. 10単位 2 日連続筋注後の流血中好酸球, 淋巴球減少 率.1）好酸球減少は図 3 の如く減少率 $50 \%$ 以上の症例は改善群 19 例中 16 例 $(84.3 \%)$, 不変群 14 例中 5 例 $(35.7 \%$ ) で推計学上 $0.9 \%$ の危険率で有意差があつた。尚不変群には A.G. 筋注後逆に好酸球 が著明に增加した症例があつた，2）淋巴球減少率 $50 \%$ 以上の症例 は図 4 の如く改善群18例中12例 (66.7\%), 不変群14例中 6 例(42.9 \%) で有意差はなかつた。 今 A.G. 筋注後 4 時間以内に減少率 $50 \%$ に達した症例をみると改善群 18例中12例 (66.7\%)，不㤎群14例中 2 例 $(15.0 \%)$ で推計学的に有意であつた。

\begin{tabular}{|c|c|c|c|}
\hline ๕8 & $\stackrel{\text { II }}{\check{m}}$ & Iさ & 5 例 $(26.9 \%)$, 不変群では 13 例中 \\
\hline in & $\dot{s}$ & & $\begin{array}{l}9 \text { 例 }(69.3 \%) \text { であうて 推計学上 } \\
2.3 \% \text { 危険率で有意であつた. }\end{array}$ \\
\hline เ & $\dot{\Sigma}$ & & $\begin{array}{c}\text { 第 } 4 \text { 節 副蜸皮犋機能の綜合的検 } \\
\text { 钨 }\end{array}$ \\
\hline in & 幽 & & $\begin{array}{l}\text { 第 } 1 \text { 篇第 } 2 \text { 章第 } 5 \text { 節に徒い検討す } \\
\text { ると } 5 \text { 種類の副孯皮简機能検查の中 }\end{array}$ \\
\hline is & Zi & さへ乞 & 3 種類以上の検査に(+)を有する症 \\
\hline 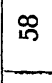 & $\dot{\Delta}$ & & $\begin{array}{l}\text { 例は改善群18例中 } 13 \text { 例 }(72.2 \%) \text { ， } \\
\text { 不変群14例中 } 6 \text { 例 }(42.8 \%) \text { であり }\end{array}$ \\
\hline ซี & $\ddot{0}$ & & 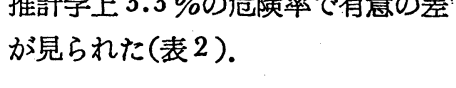 \\
\hline
\end{tabular}

第4章 小 括

私は現在 NTA 分類で軽度進展, 学研分類で $\mathrm{B}_{1}$ の現症を有する 肺結 核患者を学研の病状判定基準により 発病時より現在に至る約 2 年間にお ける胸部レ線所見改善度から判定し て改善群と不変群に分け，副腎皮貝 系機能及びトルコ鞍形を比較検討し た. 1) 117KS 1 日排泄值平均は不変 群が稍々低く，異常排泄例む多く， 推計学上有意の差があつた，2） 17 OHCS 1 日排泄值は両群共大部分が 正常範囲にあり，其の平均值に差は なかつたが両群共に健康人平均に比 し低值を示した。 3) 午前 8 時 A.G. 筋注後12時間以内の前半尿之以㷋の 後半㽷中の $17 \mathrm{KS}, 17 \mathrm{OHCS}$ につい て後半㽷の值を 1 として比率を求め ると，不変群の此率は共に改善群の 
比率より小なる傾向を示した，4）A.G. 筋注による $17 \mathrm{KS}$ 増加率平均は不変群の方が大であつた．又個々の 症例で 17KS 增加率 $30 \%$ 以上飞達したあのは不変群にやや多かつた. 5) A.G. 筋注による 17OHCS 增加率 平均は両群差がなく症例で増加率30\%以上のあのは不変群に多かつたが推計学上有意の差はなかつた。 6) A.G. 筋注後好酸球减少率50\%以上の症例は不变群に少く推計学上有意差がみられた. 7) A.G. 筋注後淋巴球 減少率 $50 \%$ 以上の症例は不变群倸く筋注柊 4 時間以内に $50 \%$ 以上の減少率を示す症例は両群間で有意差が あつた．8）不変群にトルコ鞍異常者が多く推計学上有意であつた．9）5種の副腎皮賓機能検查で 3 種以上 に(十)即ち正常值或いは A.G. 亿上く反応したと思われる症例は改善群に多く, 推計学的に有意差があつた。 以上の成績より発病時胸部レ線所見が NTA 分類で軽症或いは中等症, 学研分類で $\mathrm{B}_{1}$ 或いば $\mathrm{B}_{\mathbf{2}}$ で現在 $\mathrm{B}_{1}$ の現症を有する肺結核患者であ現在に至る迄の化学療法による胸部レ線所見の改善度の良否によつて副腎皮 機能汇差のある專が知られる。

\section{第 3 篇 肺結核症における多愁訴群と宾愁訴群の副腎皮睤系裁能について}

\section{第 1 章 検 查 対 象}

私は苦情の多い患者は予徐が比較的不良と云う経験的專実に基き発病時レ線所見が NTA 分類で軽度或い は中等度進展，学研分類で $\mathrm{B}_{1}$ 或いは $\mathrm{B}_{2}$ であつて現在迄 2 年間同一環境同一条件で加療し現在 NTA 分類 で軽度進展，学研分類で $\mathrm{B}_{1}$ 亿属する 20 才より 35 才迄の肺結核患者群を愁訴の多夏により多愁訴群と塞愁訴 群に分けた。

\section{第 2 章 研 究 方 法}

多愁訴群と 塞愁訴群につき第 1 篇第 2 章の如く副腎皮質系機能検查を行い 比較検討した。尚第 3 篇では A.G. 筋注後流血中好塩基球減少率をす測定した。 好塩基球は Moore 液染色により直接算定し減少率 30\% を基準にして検討を行つた。

\section{第 3 章 研 究 成 績}

\section{第 1 管 17KS，17-OHCS 1 日排泄值}

第 1 項 $17 \mathrm{KS} 1$ 日排泄値は寡愁訴群17例平均が $10.7 \mathrm{mg} /$ 日, 多愁訴群19例平均が7.9 は寡愁訴群 17 例中 3 例 $(17.6 \%)$, 多愁訴群19例中 7 例 (36.8\%) であり異常高值例は多愁訴群に 1 例認め られた。即ち多愁訴群は異常排泄例として19例中 8 例 (42.1\%), 㙞愁訴群で異常排泄例は 17 例中 3 例(17.6 \%) である. $17 \mathrm{KS} 1$ 日排泄值の連続 3 日間の日較変動は両群間で差がない，即ち $17 \mathrm{KS}$ 排泄值 に関しては 多愁訴群は塞愁訴群上り異常低值が多い傾向にあるが推計学上 $5.0 \%$ 上小危険率で有意ではなかつた。

第 2 項 $17 \mathrm{OHCS} 1$ 日排泄值は宾愁訴群 17 例平均 $5.54 \mathrm{mg}$ /日，多愁訴群 18 例平均 $5.30 \mathrm{mg} /$ 日であり，各症 例は共に正常範囲内にあるが健康人平均に比し一般に低值であつた。

\section{第 2 䈱 A.G. Test}

第 1 項 A.G. 10単位 2 日連続筋注による 17KS, 17OHCS 排泄值の時間的分布百分率. 1) 4前 8 時A.G. 筋注後 12 時間以内に排泄される $17 \mathrm{KS}$ 值の 1 日排泄值に対する百分率は第 1 日筋注後室愁訴群17例平均 64.6 $\%$, 多愁訴群19例平均 $53.6 \%$ であり第 2 日筋注後赛愁群 17 例平均 $64.5 \%$, 多愁訴群 16 例平均 $55.0 \%$ であつた。 今筋注後12時間目を境にして前半尿と後半尿中 $17 \mathrm{KS}$ を測定し後半尿の值を 1 として前半尿との比率を求め ると寡愁訴群平均は筋注第 $1 ， 2$ 日で其々 $1.54 ， 1.89$ であり多愁訴群平均は同じく1.16，1.20であつた．2） A.G. 筋注後12時間以内に排泄される $17 \mathrm{OHCS}$ 值の 1 日排泄值に対する百分率は夏愁訴群第一日は 13 例平 均 $70.1 \%$ ，第 2 日67.8\%であり多愁訴群16例平均は其々 $67.5 \% ， 61.5 \%$ であつた. $17 \mathrm{KS}$ と同じ椂に前半尿 と後半尿の $17 \mathrm{OHCS}$ 值の比率を求めると賽愁訴群では第 $1 ， 2$ 日は其々 $2.34 ， 2.10$ 多愁訴群では 2.07 , 1.78であうた.

第 2 項 A.G. 10 単位 2 日連続筋注後17KS, 17OHCS 增加率。1) 17KS 增加率は塞愁訴群 17例平均で 第 第34卷 第 8 号 


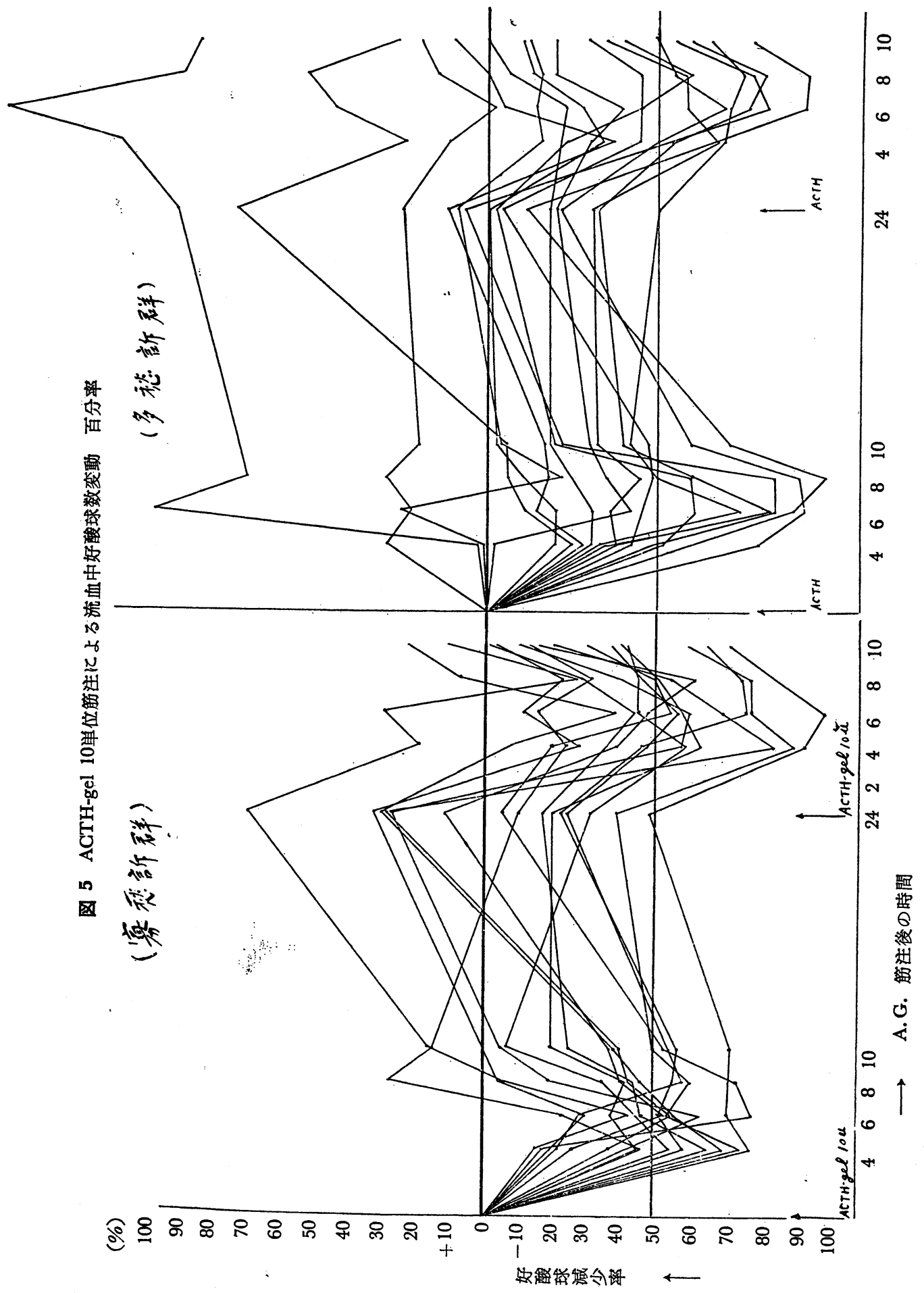




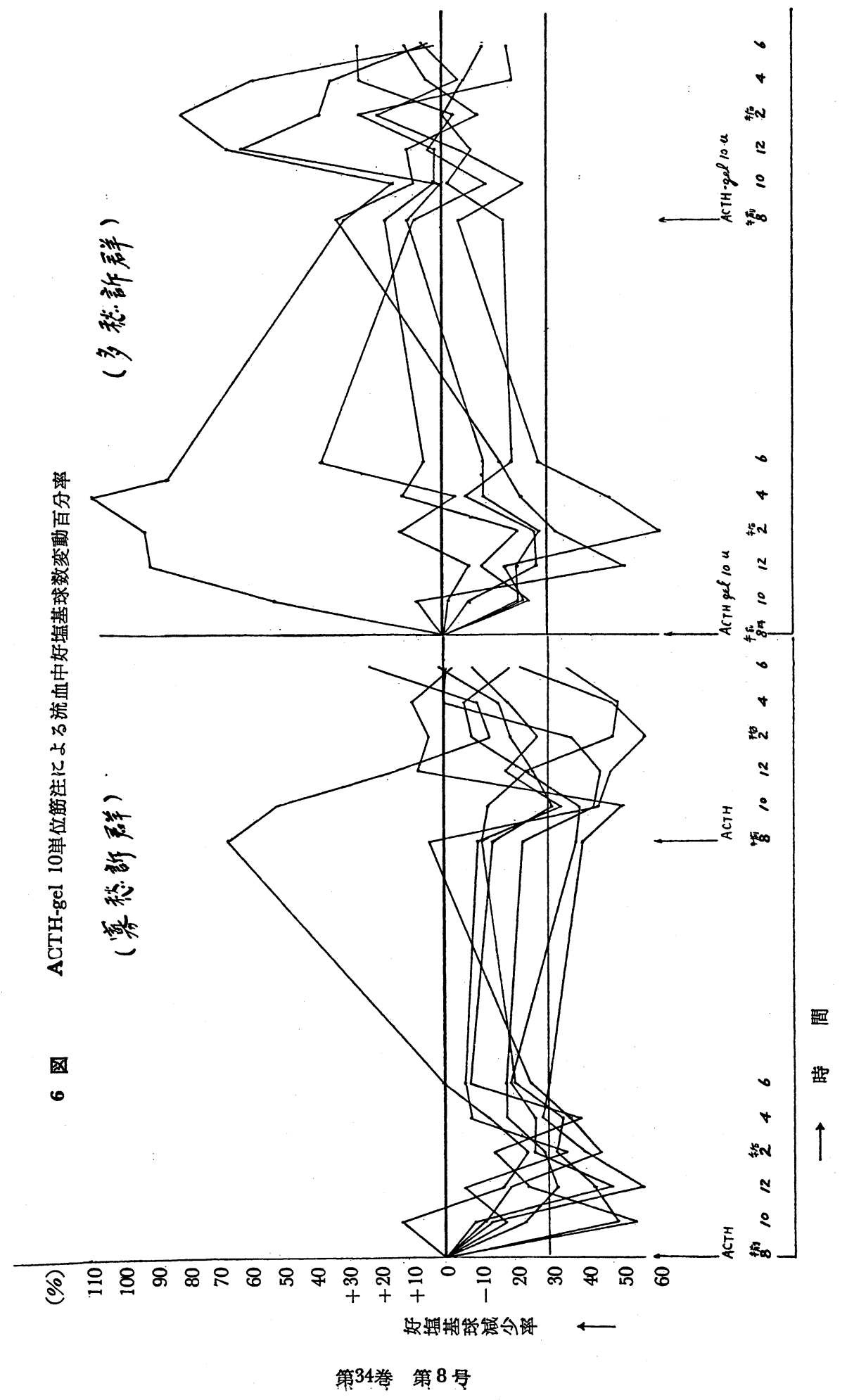




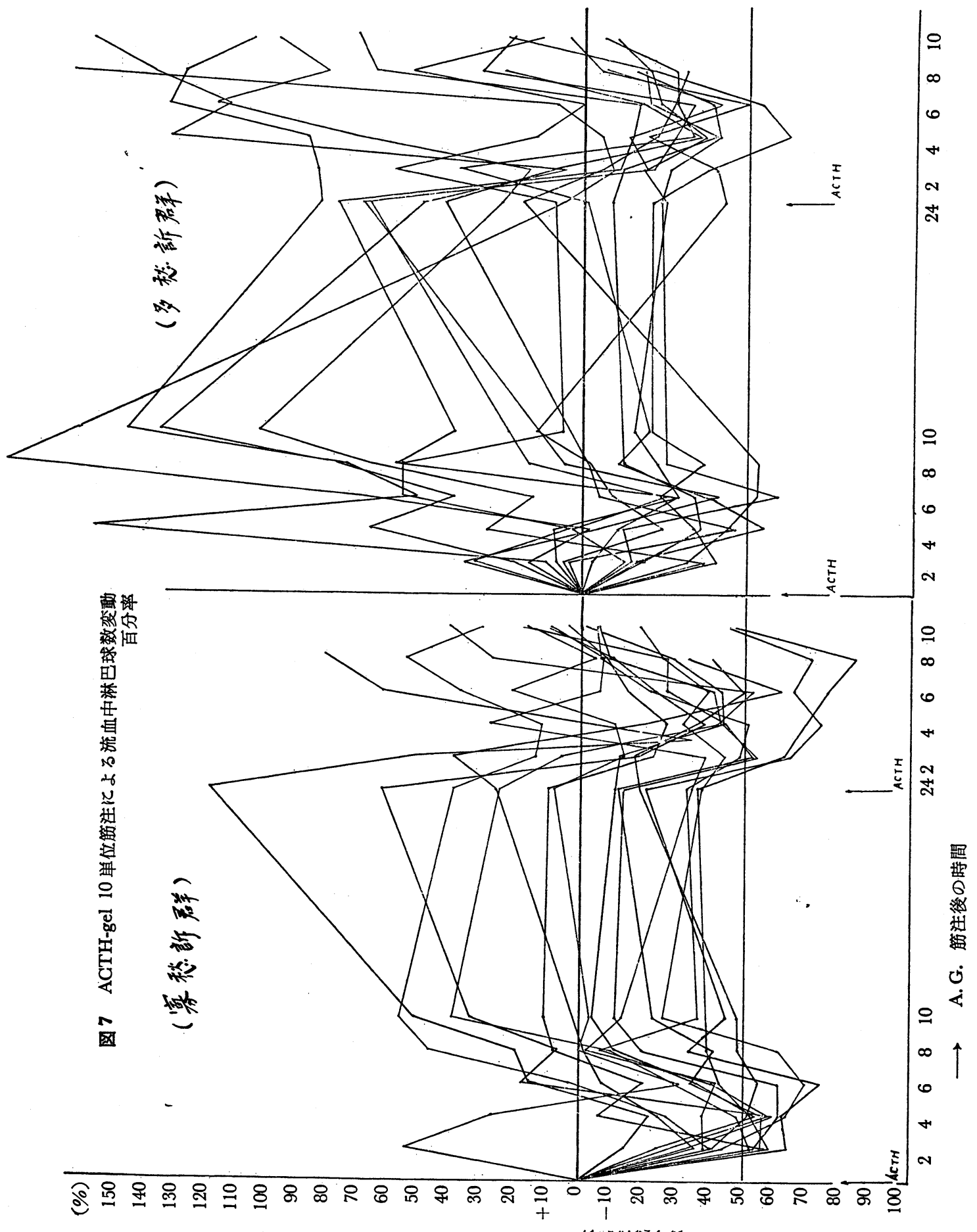

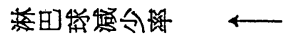




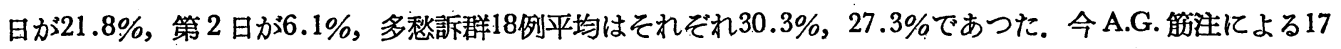
KS 増加率30\%を基準にして両群の増加率を検討してみると，30\%以上の増加率を示した症例は寡愁訴群で は17例中 6 例( $35.4 \%)$, 多愁訴群では18例中 8 例 (44.4\%) であつた。 2) 17OHCS 堌加率は宾愁訴群 13 例 平均で第 1 日 $14.9 \%$ ，第 2 日7.9\%，多愁訴群 16 例では其々 $32.2 \% ， 31.3 \%$ あつた. 又 A.G. 筋注後の增加 率の基準を $30 \%$ として検討を加えると両群で $30 \%$ 以上の堌加率を示した症例は賽愁訴群 13 例中 4 例 $(30.7 \%)$, 多愁訴群16例中 8 例 $(50.0 \%)$ であつた. しかし推計学上有意差はなかつた。

第 3 項 A.G. 10 単位 2 日連続筋注に上る流血中好酸球，好塩基球，淋巴球減少率，1）好酸球減少率は図 5 亿示す如く減少率 $50 \%$ 以上の症例は宾愁訴群 16例中13例 (81.2\%), 多愁訴群 17 例中 7 例(41.1\%)であつ て推計学上 $2.3 \%$ 危険率で有意の差があつた. 多愁訴群には A.G. 筋注後逆に好酸球が増加した症例が 3 例 ありその中 1 例は著明な増加を示した。 2) 好塩基球実数は午前 8 時に採血測定して寨愁訴群 8 例平均 48.4/ $\mathrm{mm}^{8}$, 多愁訴群 7 例平均 $31.7 / \mathrm{mm}^{3}$ であつた. A.G. 筋注による好塩基球减少率 $30 \%$ 基準にして両群で 30 $\%$ 以上の減少率を示した症例をみると図 6 の如く塞愁訴群 8 例中 7 例 $(87.5 \%)$, 多愁訴群 7 例中 2 例 $(28.6$ \%) となり推計学上 $3.6 \%$ の危険率で有意であつた. 多愁訴群中 1 例は A.G. 筋注により逆に好塩基球が著明 亿増加した. 又宾愁訴群は第 2 日 A.G. 筋注後も前日と同様 8 例中 7 例が $30 \%$ 以上の減少球を示したが多愁 訴群には30\%の減少率を示した症例は全々なかつた。 3) A.G."筋注による淋巴球减少率 50\%を基準にして両 群で50\%以上の減少率を示した症例をみると図 7 の如く宾愁訴群 16 例中12例 (75.0\%), 多愁訴群16例中 6 例 (37.5\%) となり推計学上 $4.0 \%$ 危険率で有意の差が見られた. 且う減少率50\%を示した症例の中 A.G. 筋 注後 4 時間以内に $50 \%$ に達した症例は宾愁訴群では 12 例中 11 例(91.6\%), 多愁訴群では 5 例中 2 例 $(40.0 \%)$ であり推計学上 $4.9 \%$ 危険率で有意であつた. 尚 A.G. 筋注後10時間に亘つて 全々淋巴球の減少が見られ なかつた症例が多愁訴群には16例中 4 例 $(25.0 \%)$ あつたが塞愁訴群には1 例も見られなかつた。淋巴球減 少率の動括は多愁訴群に顕著な傾向があつた.

\section{第3 筑 両群とトルコ鞍の関係}

トルコ鞍異常者は葟愁訴群17例中 5 例 (2.94\%), 多愁訴群 16例中 10例 (62.5\%) であり多愁訴群にトル コ鞍異常者が多い傾向を譛めた。

\section{第 4 管 両群と眴部レ線所見改鲁度}

現在に至る迄の胸部レ線所見改善度を学研の病状判定基準により判定した場合, 著明改善と思われる症例 は寡愁訴群 17 例中 13 例 $(76.5 \%)$, 多愁訴群 18 例中 7 例 (38.9\%) で推計学上 $2.8 \%$ の危険率で有意の相関々 係があつた。

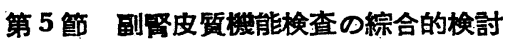

第 1 篇第 2 章第 5 節に従い検討すると，表 3 の如く 5 種類の副腎皮質機能検查中 3 種類以上の検査に $(+)$ を有する症例は宾愁訴群では16例中12例 (75.0\%), 多愁訴群18例中 8 例 (44.4\%) であつた。

\section{第4章 小 括}

私は現在同様な現症を有する軽症肺結核患者群を愁訴の多塞により塞愁訴群と多愁訴群に别けて，副腎皮 質機能，トルコ鞍形，現在に至る迄のレ線胸部所見の改善度を比軽検討した。1）17KS，17OHCS 1 日排泄 值：17KS 1 日排泄值が正常排泄域外の症例は多愁訴群に多かつた。17OHCS 1 日排泄值は両群共各症例は正 常範囲内にあつたが一般に健康人平均值より低值の症例が多数あつた。 2) 午前 8 時に A.G. 筋注後12時間 以内の前半尿と12時間以後の後半尿に排泄される $17 \mathrm{KS}, 17 \mathrm{OHCS}$ 值について後半尿の值を 1 としてその比 率を求めると多愁訴群の比率は宾愁訴群の比率より小であつた. 3) A.G. 筋注による 17KS, 17OHCS 増加 率平均は多愁訴群の方が大であり，堌加率が30\%以上の症例む共に多愁訴群に多かつた，4）好酸球減少率 が50\%に達しない症例は多愁訴群に多く推計学上有意差があつた. 5) A.G. 筋注後好坆基球減少率が30\%に 達せぬ症例は多愁訴群に多く推計学上有意の相関が認められた。 6) A.G. 筋注による淋巴球减少率が50\%以 下の症例は多愁訴群に多く, 又筋注後 4 時間以内に淋巴球の減少率か $50 \%$ 以上に達する症例は多愁訴群に少 


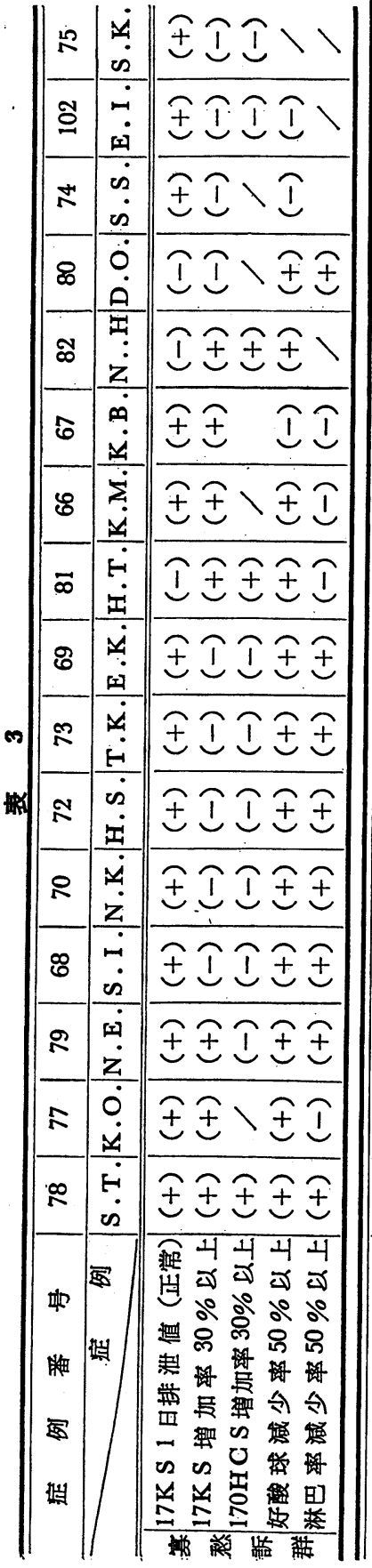

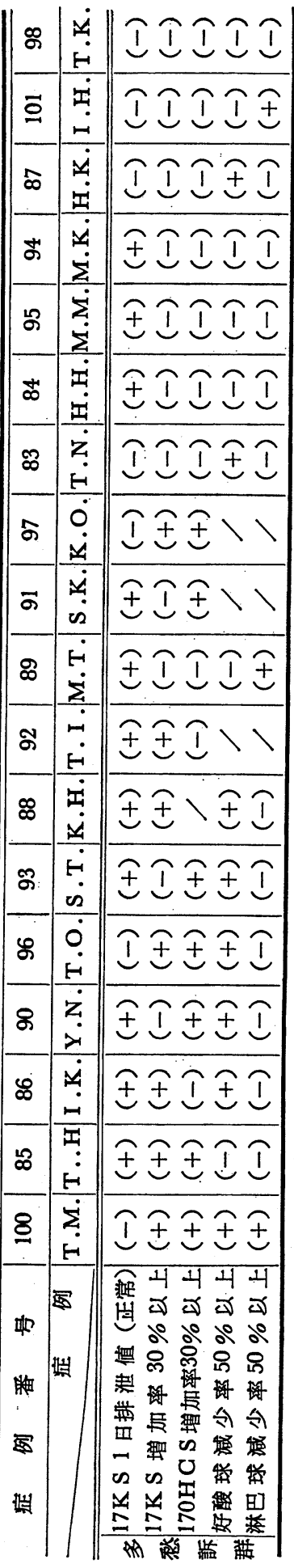

第34巻 第 8 号
共に有意なく差が見られた。7）多愁訴 群にトルコ鞍異常者が多かつた。 8) 学 研の病状判定基準による著明改善の症例 は寡愁訴群に多く，両群間で推計学上有 意であつた．9） 5 種類の副婜皮兵機能 查で 3 種類検以上に(+)即ち正常值或い は一定の基準以上に反応したと思われる 症例は塞愁訴群に多い傾向を認めた。以 上の成積より現在同椂な現在を有する軽 症肺結核患者において，愁訴の多宾によ り 2 群に分けると，両群間で副珡皮質系 機能に差が諗められ，多愁訴群に発病時 より現在に至る胸部レ線所見改善度の不 良な症例が多い事は興味がある。

\section{総括並びに考按}

私は現在同椂な現症を有する軽症肺結 核患者を 1) 既往に於いて TP 到達後化 学療法中に再発が見られ最後の TP 到達 㷋半年になる既往再発群と TP 到達後 1 年半以上再発の見られなかつた既往無再 発群. 2) 現在に至る約 2 年間の化学療 法による胸部レ線所見改善度を学研の病 状判定基準に従つて判定し改善群（著明 改善群)と不変群(軽度改善又は不変群)。 3) 愁訴の多寄により 筫愁訴群と多愁訴 群. 以上 3 つ項目で其々 2 群に分けて 副腎皮質系機能検查を行つた. 先づ 1) 17KS 1 日排泄值について 肺結核症では Rivoire ${ }^{27)}$ ，三宅 ${ }^{28)}$ は重症程尿中 17KS 值 は減少していると述へ Goldzieher ${ }^{29)}$ ，小 西 ${ }^{30}$ (は臨床症状と $17 \mathrm{KS}$ 值の関係につい て報告している. Pfeffer ${ }^{31)}$ は一般に減少 するが肺結核症の病態と平行しないと云

い Clarke ${ }^{322}$ は $17 \mathrm{KS}$ と病変の拡りは 大体平行するが为は平均正常值又はそれ 以上の值を示しているので病気の重さ以 外の因子が介入しなくてはならないとし， その理由を㭧者の情動活動に求めている のは興味深い，即ち甚しい抑䛓状態の患 者は病変の程度に拘らず正常值の50\%以 下の減少を示し反対に不安緊張の甚しい 症例はすべて正常值を $50 \%$ 以上上佪つ 
ていたと述べている．肺結核症とは别に池見 ${ }^{33)}$ は神経症㭧者の 尿中 $17 \mathrm{KS} 1$ 日排泄值は男子 15 例平均 8.61 $\mathrm{mg} /$ 日，女子 10 例平均 $7.37 \mathrm{mg} /$ 日で健常人平均に比し何れあ幾分低值であると述へておうり中瀬 ${ }^{84}$ ，徳久 ${ }^{35)}$ 同様報告を行つている，私の成䋶では，再発群，不変群，多愁訴群に於いては無再発群，改善群，蒠愁訴群 に比し 17KS 1 日排泄值が正常排泄域に達せぬ症例が多く，副腎皮質機能にある程度の異常があると考えら れる. 2) 尿中 17OHCS 1 日排泄值について. 本田 ${ }^{36)}$ は比較的重症肺結核は明白な低下があり，今泉 ${ }^{37)}$ は重 症10例平均が $5.8 \mathrm{mg} /$ 日 で低值であるが軽症 10 例平均 $8.0 \mathrm{mg} /$ 日で正常值に近づいたと述べている. 三宅 ${ }^{38)}$ は総 17OHCS は肺損傷の程度によく相関するが遊離 Corticoid は相関しない成績であつたと報告しておる. 一方石原 ${ }^{39}$ は軽症肺結核では平均 $6.77 \mathrm{mg} /$ 日であり, 重症平均は $6.89 \mathrm{mg} /$ 日で軽症と余り差がなかつたと云 つている. 私が検査対象とした軽症肺結核思者は平均 $5 \mathrm{mg} /$ 日前後であつてはぼ正常範囲にあるが健康人平 均より低値であるあのが大部分であつて, 私が分けた再発群と無再発群, 改善群と不変群葟愁訴群, と多愁 訴群で 17OHCS 值に差は認められなかつた. 3) A.G. Test そついて. Thorn ${ }^{40341)}$ により ATCH 25mg 筋 注による 副腎皮質機能検查法が提唱されてより，種々の方法が発表されたが近時 H.P. ACTH-gel 筋注 法が点滴静注法に代る便法として我が国であ井林等 ${ }^{42}$ ，鈴木 ${ }^{43}$ ，左合 ${ }^{44)}$ とり肺結核症及びその他の成績に ついて報告されている. 私は H.P.ACTH-gel 10單位宛 2 日連続筋注して検査したが先づ i) A.G. 筋注に よる尿中 $17 \mathrm{KS}$ 及び $17 \mathrm{OHCS}$ 排泄值の時間的分布百分率について。 今泉 ${ }^{45}$ は尿中の $17 \mathrm{OHCS}$ 最高排泄時 は健康人では午前 $6 〜 9$ 時，軽症肺結核患者では午前 9 時〜12時，重症肺結核では午後となつていると報告

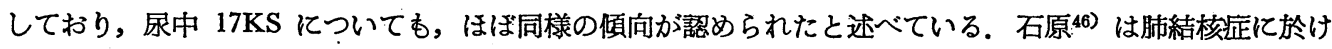
る尿中総 $17 \mathrm{OHCS}$ の排泄リズムについて軽症では最高排泄時刻は午前 8 12時で以後次第に減少し午前 4 ～8 時にやや增加する. 重症では最高排泄時刻は同じく午前8～12時であるが.（その高さは軽症に此へて高 く，他のリズムは軽症と同じであると云い，17KS には 17OHCS の如き一定の排泄リズムが無かつたと述 べている. A.G. 筋注後の排泄状熊を観察した報告はないが私は A.G. 筋注後（午前 8 時）12時間目を境と して前半尿と後半尿に於ける $17 \mathrm{KS}$ 及び $17 \mathrm{OHCS}$ 排泄值を後半尿の值を 1 として比率を述めた．私の成績 では比率は無再発群, 改善群, 多愁訴群がそれぞれ再発群, 不变群, 禁愁訴群の平均比率より大であつた。 神経症の 17KS の時間的排泄分布に関しては中瀬47)，池見 ${ }^{48)}$ の報告があり，神経症患者は 17KS の排泄 は健康人に比し朝やや低いが夕刻はむしろ高い傾吕があると云つている. 以上の成績より私は再発群，不変 群，多愁訴群は無再発群，改善群，賽愁訴群に比し A.G. に対する副腎皮貝の反応の遅鈷が推察されると思 う. ii) A.G. 筋注による $17 \mathrm{KS}$ 及び $17 \mathrm{OHCS}$ 增加率について. 今泉 ${ }^{49}$ は軽症肺結核患者 5 例に対し 3 日間 $17 \mathrm{KS}$ を測定し，その平均值を術前值として A.G. 10 単位 2 日連続筋注後の $17 \mathrm{KS}$ 堌加率を観察し增加率 が30\%に止つたと述べており，久田60) は作用持続性 ACTH (ACTON20 及び 40単位) 投与後 17KS 值の 変動は正常範闻を出なかつたと述へている，私の実験では $17 \mathrm{KS}, 17 \mathrm{OHCS} 1$ 日排泄值に相当の変動がある ので連続 3 日 17KS, 17OHCS を測定し，その平均值を前值として増加率を計算した。即ち再発群は 17KS, 17OHCS 増加率平均も $30 \%$ 以上の増加率を示した症例数も共に無再発群より小であり，不変群における $17 \mathrm{KS}$ 培加率平均及び $30 \%$ 以上の堌加率を示した 症例数は改善群より大であつたが $17 \mathrm{OHCS}$ 堌加率平均 は改善群之差がなく $17 \mathrm{OHCS}$ 堌加率30\%以上の症例は改善群に多かつた。多愁訴群は 17KS, 17OHCS 堌 加率す30\%以上の增加率を示した症例数む共に塞愁訴群上り大であつた。 iii) 好酸球減少率について. Thorn は ACTH 筋注により血中好酸球堿少を示標とする Screening Test なる ACTH-Test を発表し H.P. ACTH-gel 筋注法が報告されて臨床的に広く応用されている。

今泉 ${ }^{61}$ は.G. 筋注による好酸球減少率は軽症肺結核㭧者では対照若年者と差がなかつたと述へでわり， 小西 ${ }^{52)}$ ，美野531 は重症肺結核患者に ACTH 注射により好酸球減少率50\%以下のあのが多かつたと云つてい る. 久田 ${ }^{54)}$ は ACTH 注射による好酸球減少は NTA 分類の進展度に相関々係はないが赤沈高度促進者,

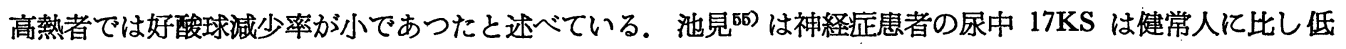
值であつたが好酸球数減少率で健常人と差はなかつたと述べている. 私の成績では再発群は無再発群に比し， A.G. 箭注による好酸球減少率が50\%に達しない症例が多く，不变群及び多愁訴群はそれぞれ 改善群及び寒 
愁訴群に比し A.G: 筋注による好酸球減少率50\%以下の症例が多く推計学上有意差がなかつた．以上より再 発群, 不変群, 多愁訴群にある程度の副留皮䨘機能低下が考えられる，iv）好塩基球減少率について，肺結核

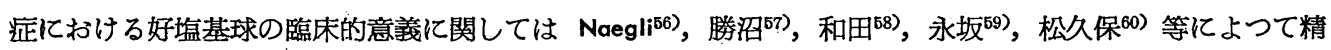
紐に研究報告がなされているが村尾 ${ }^{61)}$ ，永らは脳下垂体前葉製肪を注射するてとにより間脑下垂体系に機能 異常ある疾患において著明な好塩基球増加の起るととを慧めている。和田 ${ }^{62}$ は肺結核症においては一般と病 変が滲出性を呈する場合は好塩基球が減少し增殖性で安定期にあるすのは增加の傾向を有し好酸球の変動と 平行的であるが好酸球より反応が銛い样であると報告している. ACTH の好酸球诚少作用々ついては多く の報告があるが血液好塩基球に対する作用の報告は少ない，長田 ${ }^{63)}$ は Moore \& James の方法で ACTH 投 与時の好酸球と同時认好塩基球の変化を追求し血液好塩基球数は好酸球と共に減少し，その減少及び恢復曲 線は互に酷似するが好塩基球数の変化は好酸球数の変化より弱いと述へている. 私は A.G. 筋注による流血 中好塩基球の隇少率を $30 \%$ 基準にして検討を加え興味ある知見を得た。即ち現在同様な現症を有する軽症 肺結核患者を塞愁訴群と多愁訴群に分けて A.G. 筋注に上る好塩基球減少率をみると多愁訴群は賽愁訴群に 比し好塩基球減少率が 30\%に達しない症例が多く推計学上有意差があつた。 v）淋巴球減少率について，下 垂体副腎皮實系機能と流血中淋巴球数变動に関しては多くの研究があり Dougherty ${ }^{64) 65) ， W h i t e ， F o r s h a m ， ~}$ Hills ${ }^{66)}$ は健常人及び副腎不全を伴わない疾患では ACTH により淋巴球の明白な減少或いは減少傾向を認め ている. Sayers ${ }^{67)}$ は流血中淋巴球数変動が副腎皮質の活動性判定上有力な指標であると述べている。

吾国であ梅原 ${ }^{68)}$ ，福井 ${ }^{69}$ の報告があり池岡 ${ }^{70)}$ は ACTH に上る淋巴球減少率は好酸球減少率と一致すると 報告している. 美野 ${ }^{71)}$ は ACTH $25 \mathrm{mg}$ を健常人及び肺結核患者各10名に筋注し 2 時間後の淋巴球減少率は 其々 $13.4 \% ， 21.4 \%$ でり 4 時間後は17.2\%，13.5\%であつたと述へている. 古閑72)す AGTH 25mg 筋注 後淋巴球は $25 \%$ の減少率を示したが健常人と肺結核患者で時間的変動に差はなかつたと述べている. 今A.G. 筋注による淋巴球減少率50\%を基準にして検討してみると私の成績では再発群，不変群，多愁訴群は無再発 群，改善群，塞愁訴群に比し堿少率50\%以下の症例が多く再発群と無再発群，多愁訴群と塞愁訴群の間には 其々推計学上有意差があつた. 又 A.G. 筋注後 4 時間目が淋巴球減少率は最高であり, 筋注後 4 時間以内に 減少率が50\%に達した症例は再発群，不変群，多愁訴群に少なく其々無再発群，改善群，寡愁訴群との間で 有意差があつた． 7）トルコ鞍について。トルコ鞍と下垂体副留皮質系の関係を論じた研究は高木 ${ }^{73)}$,久金 ${ }^{74)}$, 泉75)らにより報告されており，古䦙76)も下垂体機能とトルコ鞍について報告している，泉は肺結核症の臨床 をトルコ鞍像を中心とした研究報告でトルコ鞍異常形に属するすのは自律神経系機能が不安定な状態にあり Thorn Test, Praehormon Test 共江異常反応を呈するすのが多く間脳下垂体副珼皮質系の 機能異常が認め られ外力に対する生体反応の異常となり結核症における発病，経過，予後に悪い影響を与えるものと思らと 述べている。私はトルコ鞍形より再発群, 不変群, 多愁訴群は夫々無再発群, 改善群, 寡愁訴群に比しトル コ鞍䔬常者が多く不変群と改善群との間では有意差があつた。以上より現在同様な現症を有する軽症肺結核 患者にわいて再発群と無再発群，化学㙩法中の不変群と改善群，多愁訴群と寒愁訴群の副留皮質機能に差が 見られた事は興味があり，ての事よりして副腎皮質機能の良否が結椟症の経過とくに再発或いは悪化と関係 がある様に推察される。

\section{結論}

私は対象結核患者を次の 3 つの項目について夫々 2 群に分けた. 即ち 1) 現在 NTA 分類で軽度進展, 学 研分類で $\mathrm{B}_{\mathbf{1}}$ に属し TP に達している20才〜40才汽の肺結核患者群を曾つて TP 到達後の化学療法中に再 発の見られた既往歴を有し最後 TP 到達後半年以上経過した所の既往再発群と TP 到達後 1 年半以上再発 を見なかつた既往無再発群に分けた．2）現在 NTA 分類で軽度進展，学研分類 $\mathbf{B}_{1}$ の現症を有する20才〜 35才迄の肺結核患者群を発病時胸部レ線所見が NTA 分類で軽度進展か中等度進展, 学研分類で $\mathrm{B}_{\mathbf{1}}$ 或い は $\mathrm{B}_{2}$ であり同一環境同一条件で加療し発病後現在に至る約 2 年間の化学療法による胸部レ線所見を学研の 病状判定基準で判定し改善群（著明改善群）と不変群（軽度改善又は不変群）に分けた，3）登病時胸部レ 
線衣見が NTA 分類で軽度或いは中等度進展, 学研分類で $\mathrm{B}_{1}$ 或いは $\mathrm{B}_{2}$ であつて 現在迄約 2 年間同一環 境同一条件で加療し現在 NTA 分類で軽度進展, 学研分類で $\mathrm{B}_{1}$ の20才〜35才迄の肺結核患者群を多愁訴 群と賽愁訴群に分けた。

1. 尿中 $17 \mathrm{KS}$ 一日排泄值

苒発群, 不变群, 多愁訴群に尿中 $17 \mathrm{KS} 1$ 日排泄值が正常排泄域に達しない症例が多かつた。

2. 尿中 $17 \mathrm{OHCS} 1$ 日排泄值

各群とも正常範囲内の症例が大部分であつたが健常人平均值より低值の症例が多く各群間で差はなかつた。 3. ACTH-gel 10単位 2 日連続筋注による尿中 17KS, 17OHCS 值の時間的分布

ACTH-gel (A.G.) を午前 8 時に筋注後12時間目を境にして前半尿と後半尿に分け，後半尿中の17KS, 17 OHCS 值を 1 として前半尿中の $17 \mathrm{KS}, 17 \mathrm{OHCS}$ 值との比率を求めると再発群, 不変群, 洺愁訴群の各比 率平均は無再発群, 改善群, 寒愁訴群の各比率平均上り小であつた。

4. ACTH-gel 10単位 2 日連続筋注による尿中 $17 \mathrm{KS}, 17 \mathrm{OHCS}$ 增加率

再発群は $17 \mathrm{KS}, 17 \mathrm{OHCS}$ 堌加率平均も增加率30\%以上の症例数も共に無再発群より小であつた，不变群 の $17 \mathrm{KS}$ 増加率平均及び $17 \mathrm{KS}$ 増加率 $30 \%$ 以上の症例数は改善群のそれより大であり.17OHCS 増加率平 均は改善群と差がなく,17OHCS 增加率 $30 \%$ 上上の症例数は改善群に多かつた.多愁訴群は $17 \mathrm{KS}, 17 \mathrm{OHCS}$ 増加率平均む $30 \%$ 以上の増加率を示した症例数む共に塞愁訴群より大であつた。

5. AGTH-gel 10單位 2 日連続筋注に上る流血中好酸球減少率

再発群, 不変群, 多愁訴群に好酸球减少率50\%以下の症列が多く, 不变群と改善, 多愁訴群と㙞愁訴群で は推計学上有意差があつた。

6. ACTH-gel 10単位 2 日連続筋注による流血中好塩基球減少率

第 1 篇と第 2 篇では測定しなかつた。第 3 篇の多愁訴群は宾愁訴群に比し好塩基球减少率 $30 \%$ 以下の症例 が多く推計学上有意の差があつた.

7. AGTH-gel 10單位 2 日連続筋注による流血中淋巴球娍少率

再発群，不变群，多愁訴群に淋巴球減少率 $50 \%$ 以下の症例が多く再発群之無再発群，多愁訴群と塞愁訴群の 間で有意の差があつた.

8. トルコ鞍形態との関係

再発群，不恋群，多愁訴群にトルコ鞍異常者が多く，不变群と改善群の間で有意差があつた。

9. 副婜皮質機能検查の総合的検討

17KS 1 日排泄值正常. ACTH-gel 笳注による 17KS, 17OHCS 增加率30\%以上. ACTH-gel 筋注後流血 中好酸球，淋巴球減少率 $50 \%$ 以上のての 5 種類の検查で 3 種類以上の検查を満足する症例は夫々無再発群， 改善群, 宾愁訴群に多く無再発群と再発群, 改善群と不変群では有意差があつた。

即ち現在同樣な現㱏を有する軽㱏肺結核患者でも 既往における TP 到達後の化学療法中の 再発の有䓡， 化学㙩法中の胸部レ線听見改善度の良否, 愁訴の多宾により副腎皮貝機能に差が見られ既往再発群, 軽度改 善又は不変群，多愁訴群は夫々既往無再発群，著明改善群，塞愁訴群に比し副腎皮質機能低下がある樣思 われる. 又とのととよりして副腎皮質機能の良否が結核店の経過特に再発又は悪化と関連がある様に推察さ れる。

擱筆するに臨み御指導御校閲を賜わつた恩師日比野教授にお礼を申し上げます，尚終始御指導御鞭撻を賜 わつた国立愛知療養所長久野博士並び亿医務課長稲田博士，内科医長泉博士，左合学士に感謝致します。

本論文の要旨は四和 32 年 5 月日本結核病学会東海地方会第 13 回総会，32年 10 月第12回国立病院療養所綜合 医学会，32年11月日本結核病学会東海地方会第 14 回総会, 昭和 33 年 5 月第 33 回日本結核病学会総会付扣いて 発表した. 
1) Selye, H. : J. Clin. Endocrinol. $6: 117,1946$.

2) Fineston, J. \& Shuman, C.R. : Ame. Rev' Tbc, $64-6: 630,1951$.

3) Gny, D. Campbell, Ray, H. Biggs \& Henby Bòswell : Ame. Rev. Tbc, 66-3 : $364,1952$. 4)29) Goldzieher, J.W. : Dis. of Chest, 23-6:667, 1953.

5) Edmined, R. Clarke

et al. : Ame. Rev. Tbc, 69-3 : 351, 1954.

砂原茂一：ホルモンと臨床，1４：296, 1953. 小川漠 : 結核, 28〜9 : 419, 1953. 人 : 結核, $29 \sim 3: 111,1954$. 小西太郎：医療，8１1: 665，1954. 山崎正保 : 綜合臨床, 4 15:675, 1955 .

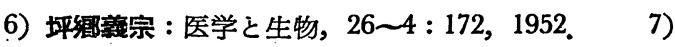
8）小川鍳 : 結核，28８:361，1953.
11）成松蘶 14)24)

12）山崎正保: 日本臨床結核，14４：362，'1955. 15)30)52）小西太郎：医療，8～12:746, 1954 .

1954.

18）泉济弥：日本内分泌会誌，30６：377，1954.

17)25)26)75）泉湆弥：日本内分泌会誌，30５:305,

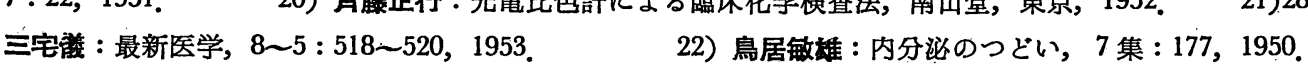
23)42）井林博他：最新医学，10〜8：169〜170，1955. 26）田宮知耻夫：レントゲン彭断学吕巻, 内山堂. 27) Rivoire, R. : J. press. Med, 764, 1954, (7)より引用. $\quad 31$ ) Pfeffer : Deut. Med. Woch, 22 : 727, 1951，(7)ょり引用. $\quad 32$ ) Clarke, E.R., Zahm, D.W. \& Holmes, T.H. : Ame. Rev. Tbc, $69: 315,1954$. 33)48)55）池見西次郎 : 日内分泌会誌，32～2: 97，1956.

34)47) 中瀬涉 夫：日内分泌会誌，30３：180，1954. 35）徳久梯次郎：日内科学会誌，45９：1004，1956. 36）

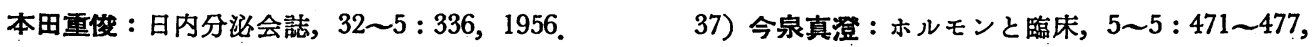
1957. 38）三宅儀：日本内科学会誌，49：46，1956. $41 \sim 11: 740,1953$. 40) Thorn, G.W. : J. Clin. Endocrinol. a Metabol. 13 : 614, 1953.

Thorn, G.W. : J. Glin. Endocrinol. a Metabol. 13 : 604, 1953.

$9: 763,1956$.

44) 左合昌者 : 結核,
43）鈴木幸三.・日内分渡会誌，32～ 45)49)51）今泉真澄：日本臨床
結核，15 10: 710 712，1956.

53）美野真一 : 内科の領域, 3〜7:350〜357，1955. diagnostik 5Aug. 1931 .

57) 㮩沼精蔵：日内科学会誌, $23: 1 \sim 139,1935$.
56) Naegeli, O. : Blutkrankheiten u. Blut-

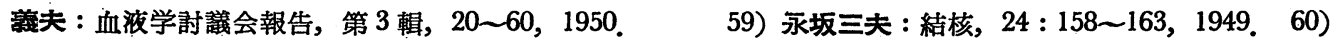
松久保香 : 名古屋医学 : 72 23 :

61）村尾実：日血液会誌，1：1～12，1937，63） 带田泰公：国立公采衛生院研究報告，4１，2：9，1954.

64) Dougherty; T.F. a. A. White : Endocrinol. $35: 1$ 1944, 66)上り司用。

65) Dougherty, T.F. a. A. White : J. Lab. \& Clin. Med. 32 : 584 1947, 66)ょり引用.

66) 日比野進 : 医学のあゆみ : 別冊 $3: 53$ 65，1955,

67) Sayers, G. : Physiol. Reviews, 30 : 241, 1950, 66)より引用. 68) 梅原士治：最新医学, 8〜 9 : 1063, 1948 . 69）福井定光：日血液会誌，18４ $\cdot 280 ， 1950$. 70) 池网清之 : 大阪大学医学雑誌, 8～910 : 1185,

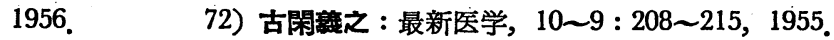

73) 高木呈治 : 結核, $25: 526$, 1950. 74）久金彰：名古屋医学会雑誌，65:112，1951. $31 \sim 2: 83,1955$.
76）古閑羲之：日内分泌会誌, 